tidy description of a completed personality. This may be an important source of our difficulties. We demand integration and adaptation; but an integration so complete that all responses are psychologically automatic has gone beyond maturity. The person is over-ripe. Variability must be preserved for adequate living. It is as important as intelligence or emotional development, and must somehow be integrated with them in fact and in theory. We must insist that maturity is not only compatible with, but also includes essentially an intellectual restlessness and a striving for the unattained. When the capacity for development is lost, death has set in. It would be easy to construct a plausible description of maturity which equated it with mental death. We are now on the way to answering one of Pear's questions. The truly mature personality, having retained at full strength the capacity for change and adventure, will consequently appear juvenile, and perhaps capricious. When tasks are not pressing upon him he will become sportive and (at least in the eyes of those already mentally dead) rather ridiculous.

My concept of maturity demands that the mature and wise should at times permit themselves to be silly, and those who dislike the word can look up its etymology. When I was interviewed at the outset of my university career, the principal insisted upon my joining him in shooting at a copy of The Times with toy bow and arrows. This was not an early example of 'selection procedures'. He just felt like that, and there were many equally surprising moments in the years that followed. Nevertheless, I rank him among the great and wise of his day. The 'sense of humour' is another facet of this trait, implying a capacity to see things in a novel light, to change relations and to respond in an unexpected way. But admittedly a capacity for the unexpected is poor material for science, and perhaps beyond assessment by exact measurement. So by this route also we only reach what Pear might call 'Tudorbethan' thinking-just better than none at all. But we are gaining control of the concepts of development of specific traits, of integration, and of variation of response. Having these, need we continue to employ a term like 'maturity', which inevitably carries an ethical and emotional tinge ? We shall be well advised to use it only with the restricted connotation relevant to the immediate context. Even so, let us bear in mind Aristotle's dictum. "We must be content if we can attain to so much precision in our statement as the subject before us admits of : for the same degree of accuracy is no more to be expected in all kinds of reasoning than in all kinds of handicraft". It may be added that those who desire to study thoroughly and constructively the nature of maturity might well begin with the "Nicomachean Ethics".

Lastly, encouraged by a recent conversation with Prof. Bott, let me suggest a new turn to the discussion. We judge that a particular reaction is mature. We cannot safely judge that the personality is mature. Though the whole personality may have been brought to bear upon the act, it is not limited thereto. A human personality is extended in time as the physical organism is in space and time. One is no more present at a point in time than is the other at the intersection of certain spacial coordinates. It may be convenient to overlook this in rough-and-ready speech. Cross-sections and momentary aspects are indispensable means of knowledge, but they can never give full truth. "Call no man happy until he's dead" is not pessimism but sound science, for the total man has not existed until that moment. So with maturity. The term is applicable to an epoch rather than to an instant. It is a history, not a static quality. We may picture life as an ascent to an undulating plateau followed by a drop to zero, abrupt or gradual as fate decides. ' $X$ is mature' will be a true statement if the history of a substantial section of the total life of $X$ shows the characters which we deem to be significant. One may occasionally be permitted to be less austere, but we shall walk in sticky mud if we insist on applying terms appropriate to the full and continuous temporal extension of personality as adjectives for single moments or assemblies thereof. Indeed, until psychologists deal far more resolutely than they have done with the temporal aspects of mental life, they must be judged to be scientifically immature.

\footnotetext{
1 Pear, T. H., "The Concept of Mental Maturity" (Manchester University Press, 1944).

2 Pear, T. H., "The Maturing Mind", 146.

"Wolters, A. W., 'On Conceptual Thinking”, Brit. J. Psychol., 24. - Pear, T. H., “The Concept of Maturity", 15.

s "Nicomachean Ethics", I.3.1.
}

\section{SCIENCE IN KWEICHOW AND KUANGSI}

\author{
By DR. JOSEPH NEEDHAM, F.R.S. \\ British Scientific Mission in China
}

$\mathrm{A}$ FTER some lapse of time, the opportunity again presents itself of continuing the series of articles on science in China in war-time, of which seven have already appeared in Nature. In this and the following article, on China's far south-east, I shall be describing an area which I visited in the summer of 1944 , just before the tide of war overwhelmed nearly all of it, wrecking many scientific installations, and forcing many of the scientific workers I met to take to the roads in evacuation or to the mountains in dispersal,

Taking the city of Chungking as the central point of China, this area is China's south-eastern quarter, To enter it the traveller must follow the southern road from the capital, winding over half a dozen passes through the protecting mountains, until he reaches Kweiyang, the capital of the relatively barren and rocky province of $\mathbf{K}$ weichow. A fow hundred kilometres south-east of this city is Tushan, the rail head of the uncompleted $\mathrm{K}$ weichow-Kuangsi railway and here he may entrain for the descent through mountains wreathed in cloud to the fertile plains and rolling hills of Kuangsi around the city of Liuchow The capital of Kuangsi is, however, farther east, at Kweilin, amidst that extraordinary scenery of 'Karst limestone pinnacles and sugar-loaf hills rising abruptly out of the plain which justifies to the incredulous foreigner the fidelity of Chinese scroll-paintings, Thence the railway goes on the east, bearing north to Hêngyang and then south to the temporary railhead at Kukong in Kuangtung.

Between Chungking and Kweiyang at a small town called Tsunyi is to be found Chekiang University, one of the best four in China. Housed largely in old and dilapidated temples, there is not enough room for all of it at Tsunyi, so the scientific faculties are situated at a very pretty and very small town, Meitan, some $75 \mathrm{~km}$. away to the east. It is typical of the present transport situation in China that although the University started with three trucks and a car 
to maintain its communications, all have long ago broken down and are unrepairable and unreplaceable, so that eminent and aged scholars such as the deans of faculties on their necessary journeys have to perch on the top of loaded army trucks on a trip which may take two days, over a road passing through very few inhabited places.

The president of Chekiang University is Dr. Chu Ko-ching, China's leading meteorologist, who is concurrently head of the Academia Sinica Meteorological Institute. At. Meitan one finds a hive of scientific activity. The Biological Department, headed by Dr. Bei Shih-Chang, a pupil of Spemann, Harms, and Hertwig, has been working on induction phenomena in regeneration in cœlenterates, insect hormones, etc. Here also at the time of our visit was the eminent geneticist Dr. Tan Chia-Chen, whose work on the curious colour-pattern inheritance in ladybird beetles is now arousing much interest in the United States, where he has gone for a year's visit. In chemistry there are Dr. Wang Bao-Rjêng (a pupil of $\mathbf{J}$. $\mathbf{F}$. Thorpe's), working on sulpha-drug derivatives (some of which have been found to be active as plantgrowth hormones), and Dr. Wang Chin, a specialist on microanalysis and the history of Chinese alchemy. This very active-minded group is completed by Chang Chi-Kai, a German-trained specialist on local anæsthetics, and by Sun Tsung-Pêng, Americantrained biochemist.

In physics, work is proceeding mostly on theoretical lines owing to lack of apparatus, in nuclear physics, geometrical optics, etc.; but the level is distinctly high (Drs. Wang Gan-Chang, an Edinburgh man, Ting Hsu-Bao, Ho Tsêng-Lu, a pupil of Millikan's, and the promising Chêng Kai-Djia). There is a special mathematical institute directed by the geometer Dr. Su Bu-Chin.

The Agricultural Research Institute, with a large area of experimental plots, is also doing much work. Dr. Lo Têng-Yi, in biochemistry, has discovered a high vitamin content in the large hips of the local wild rose Rosa multiflora (20 mgm. ascorbic acid per gm., and $30 \mathrm{mgm}$. vitamin $\mathbf{P}$ per gm.), and some 35 mgm. per gm. of vitamin $P$ in the Chinese 'date', or 'jujube' as it should be called, Zizyphus vulgaris. Dr. Bai Han-Hsi, in the fermentation division, is studying the interesting Kweichow 'barm' used in making the famous 'mao-tai' wine, which, besides its yeast, contains no less than twenty-eight special added drugs, some of which accelerate saccharification while others probably inhibit contaminating microorganisms. This recipe is an extraordinary example of a procedure with centuries of trial and error work behind it, ensuring good results under country conditions where no sterilization precautions are taken. It even has a war importance, for a certain proportion of the power alcohol used by Allied military trucks upon the roads of China is distilled from spirits prepared in the traditional way by the farmers, and brought to central distilleries. In soil science, under Dr. Pêng Chien, investigations on soil $p \mathbf{H}$ are in progress, and on trace elements, nickel, zinc, etc., with special reference to tea, legume, and vegetable culture.

In Tsunyi, there is also the All-China Sericultural Research Institute, where very solid work, led by Dr. Tsai Bao, goes on.

At Kweiyang, a larger town than either Tsunyi or Meitan, we found a number of scientific organizations. The largest was the Army's Emergency Medical Service Training School in a beautiful wooded valley among hills called Tuyünkuan; but besides this there were two civilian medical schools, Hsiangya Medical College and Kweiyang Medical College. There was also the $\mathrm{K}$ weichow University, situated some $20 \mathrm{~km}$. to the west of the town in the famous park of Huachi. There was a branch vaccine laboratory of the National Epidemics Prevention Bureau, a branch of the National Agricultural Research Bureau, a number of important industrial enterprises including a lowtemperature carbonization plant and a chlorate plant, and several plants of the Ordnance Administration. About $150 \mathrm{~km}$. to the west, at a pretty town called Anshun, there was the regular Army Medical Colloge. Finally, within Kweiyang eity, there was the Provincial Science Institute. Among such a wealth of worthwhile institutions, there is space to mention only a few salient points of interest.

The Tuyünkuan College was originally organized by Lieut.-General Robert Lim (Ling Ko-Hsing), the internationally known Edinburgh physiologist. It trains all grades of medical workers for the army, alternating laboratory courses with experience in the field. Dr. Chen Wên-Kuei's model vaccine plant and bacteriological laboratory deserve mention; Dr. Ling Fei-Ching is studying the penicillin production of the indigenous strains of Penicillium. An interesting and valuable X-ray apparatus repair station (the only one in China) is directed by her husband, Dr. Rjung Tu-Shan. In teaching chemistry, Dr. Li Kuan-Hua has organized extremely ingenious semimicro methods which it was a pleasure to see in use by his classes. The reagent sodium tungstate was being manufactured here. The Hsiangya Medical College (Dean Chang Hsiao-Chien, a pupil of Krogh's) had some wretched buildings; but excellent men, such as Dr. Chêng Wên-sse the pharmacologist, studying the Chinese drug 'Yadantze' which has an emetine-like action in dysentery. The Kweiyang Medical College (President Li Tsung-En, trained at Glasgow) has the distinguished pathologist Dr. Li Yi, and among her colleagues the American-trained embryologist Dr. Chang Tso-Gan. The psychiatrist Ling Ming-Yo represents a field hitherto little cultivated in China. Both these medical colleges were running up-to-date teaching hospitals.

Two of Zinsser's pupils in Kweiyang, Dr. Wei Hsi, of the National Epidemics Prevention Bureau branch laboratory, and Dr. Liu Pin-Yang of Hsiangya, were engaged upon a very interesting project, namely, the cultivation of typhus Rickettsia bodies in the cœlomic fluid of silkworm larvæ and pupæ (in which good growth is obtained) instead of the yolk-sac of the chick embryo. If this method could be used successfully, it would greatly simplify the preparation of the Cox vaccine under Chinese conditions, where incubators are not available but silkworms are.

The regular Army Medical College at Anshun (director, Lieut.-General Chang Chien) is located outside the town on an airy moorland in a spacious old Ching dynasty barracks, with the various institutes scattered around in scenery like that of the Scottish Highlands. The most important institutes are those of bacteriology, directed by Major-General Li Chen-Pin, and of nutritional science, under Dr. Wan Hsing. Li Chen-Pin, when at the Rockefeller Institute in younger days, carried out classical work with T. M. Rivers. Rivers and Goodpasture were the first to cultivate viruses on the chorio-allantoic membrane of the chick embryo; Rivers and Li were the first to cultivate them (vaccinia and yellow fever) on explanted fibroblasts. Yellow fever vaccine is still 
prepared in this way. Unfortunately, lack of equipment prevents much research in these institutes, though manufacture of vaccine goes on. The pharmaceutical institute maintains a model factory in which there is a certain production of drugs, and there is a good pharmaceutical garden and farm under Dr. Kuan Kuang-Ti. The Army is planting in Szechuan hundreds of thousands of seplings of the tree Dichroa febrifuga, from which is derived the drug 'changshan', known in the Chinese pharmacopœia at least as far back as the Sung dynasty, and recently found in both London and Chicago to have a parasitocidal action in animal malaria.

One of the best types of institution in the Chinese development of the sciences has been the provincial science institute. Reference has already been made to certain of these seen in other provinces; but the one at Kweiyang, directed by Dr. Ling Shao-Wên from the Emergency Medical Service Training School, was extremely good. For popular education there were really good exhibits of parasitology, highway engineering, war gases, embryology (including man), geology and mineralogy, and nutrition. A splendid room, prepared by Mr. Liu Ting-Wei, a great authority on the subject, demonstrated the life-cycle of the Kweichow wax-insects, allied to aphids. This indigenous industry gives a large annual production of highest-quality wax, and both the insect life-cycle and the industrial methods are very curious. The Provincial Science Institute also manufactured scientific apparatus for schools, and had been planned with spacious centralized laboratories for school practical work; but in war-time it had proved impossible to equip them.

If the exhibitions at the Kweiyang Science Institute were the best I had seen, the apparatus manufactured at the Kuangsi Science Institute was the best of its kind. A good many reading machines, for use with the microfilmed journals sent out by the British Council and the State Department of the United States, have been made here. The Institute, which had an excellent building, adjoined those of Kuangsi University (president, Li Yün-Hua, a chemical engineer) around a sloping patch of grass in the hills, rather resembling an English village green, at Liangfêng, some $25 \mathrm{~km}$. south of Kweilin. Near by, among groves of pine trees, were the wooden buildings of the Academia Sinica Institutes of Geology (under the internationally known Dr. Li Se-Kuang (J. S. Lee), of Physies (under Dr. Ting Hsi-Ling), and of Psychology (under Dr. Tang Yueh).

When I was there, Dr. Li was partieularly interested. in the distortions produced in stone under glaciation, analogous to the 'bending' of tombstones, etc. Work was proceeding on palæobotany (Sse Hsing-Chien), Kleintektonik (Chang Shou-Chang), and mineral ore structure (Wang Yin-Chih). Associated with Dr. Ting was Dr. Parker Chen (Chen Tsung-Chi), the wellknown former colleague of Sven Hedin. Away in the hills a very fine terrestrial magnetism station was working; located in a specially built non-magnetic and thermostatic house, it took continuous photographic recordings of all three elements, and possessed excellent apparatus, some of it made in the Institute's own workshops. The smallest of the three Institutes was that of Psychology (really developmental physiology of the nervous system); Dr. Tang was carrying out transplantations on the beautiful transparent tadpoles of Microhyla ornata. There was a particularly good library of neurology and experimental morphology, housed in a separate building.
Probably the best scientific department of Kuangsi University was that of chemistry. Here Dr. Amos Pêng (Pêng Kuang-Chin) was working hard with his group on the indigenous plants which contain rubber in their sap. Several useful new sources in Kuangsi have been found, notably the climbing fig Ficus pumila and the giant vine Chonomorpha macrophylla. Many experimental articles have been made from these rubbers.

The other most outstanding scientific institution in Kuangsi province was probably the Ministry of Agriculture's Experiment Station at Shatang, near Liuchow, covering 7,000 acres and comprising many good laboratories. Directed by Dr. Ma Bao-Chih, the translator of 'Sturtevant and Beadle' and other important books, it was a scene of great activity. Choosing at random from among the divisions, Dr. Huang Liang (economic entomology) demonstrated the bamboo comb designed for use by the farmers to get the caterpillars of the rice skipper, Parnara guttata, off the rice plants, and the box coated inside with a sticky mixture of pine resin and teaseed oil, for getting the flea beetle, Phyllotreta vittata, off the cabbages. Dr. Chang Hsin-Chêng (a pupil of Waksman) demonstrated the production of inoculum of root-nodule bacteria. Particular attention was being paid to sugar-cane improvement, tung-oil tree (Aleurites fordii) culture, rice selection, and storage of citrus fruits. Dr. Huang Rjui-Lun had shown that during the storage of the pomelo or 'yudze', the ascorbic acid content actually rises, up to a maximum. Attention was being paid to naturally occurring insecticides.

Circumstances have forced me to make considerable use of the past tense in this article. It will be remembered that in last year's campaign, the Japanese, starting from Changsha as a focus on the southern edge of the Japanese-held north-east quarter of China, pushed down to Hêngyang, cutting off the far southeastern provinces, and then successively down to Kweilin, Liuchow, and Nanning, thus acquiring a corridor with Indo-China. From Liuchow they pushod up the railway to railhead at Tushan and a little beyond, but stopped at the frontier of Kweichow, not however without having caused a partial evacuation of Kweiyang. What happened to the scientific workers?

It is sad to have to record that the Liangfêng centre was practically destroyed. The Academia Sinica Institutes evacuated their personnel to Chungking, but lost a great deal of apparatus which could ill be spared. The Library of the Institute of Psychology was almost completely lost. Kuangsi University personnel were evacuated into the mountains west of Liuchow and have not been heard of since. Both the Provincial Science Institutes were ruined, that at Liangfêng by the Japanese, and that at Kweiyang, with its laboriously arranged exhibitions, by having Chinese troops quartered in it and being "put in a posture of defence". The Shatang agricultural station was overrun; but it is believed that the records were evacuated in time. It is to be feared that some scientific workers and their families were caught in the congested refugee areas at railhead, where the mortality was appalling. I myself met Mrs. Chou, the wife of the Fukienese physicist Chou Chang-Ning (a Cavendish man), on the station platform at Liuchow just before the fall of Kweilin, and did what I could to assist the onward journey of her and her children. Fortunately, Tsunyi, Meitan, and Anshun were not affected; but Kweichow University was, the students 
and professors simply setting out to walk, carrying what books and apparatus they could, as if it were a thousand years ago. This University has now reassembled at Huachi. Hsiangya and Kweiyang Medical Colleges, however, managed to secure some truck transport and moved to Chungking, where they are remaining for the time being.

Western Kuangsi was recaptured early this year from the Japanese, but in a ravaged state. The city of Liuchow, for example, was burnt to the ground. The scientific development of these provinces was just in its opening phase, stimulated by the evacuation from the coastal cities; it has been distressing to see so cruel a frost nip it in the bud.

\section{OBITUARIES}

\section{Sir David Milne-Watson, Bt.}

A Leading national industry and a wide circle of friends and admirers will regret the death on October 3 af David Milne-Watson. He was one of those Scotsmen possessed of unbounded energy and enormous capacity for work who, trained as a lawyer, developed great administrative and organizing ability coupled with a facility to understand human nature which made him a great leader of men of all grades of society.

Born in Edinburgh in 1869, he gained two degrees at the University before entering a law office. Something lured him to Balliol College, Oxford, and from there he completed his education at Marburg. $\mathrm{He}$ was tempted by politics like many young lawyers of his time and contested the South-Eastern Division of Essex in 1895. Fortunately for the gas industry he was unsuccessful, and though he was called to the Bar in the next year we find him attracted into industry in $\mathbf{1 8 9 7}$.

A large statutory company like the Gas Light and Coke controlled by various Acts of Parliament has need from day to day of the best legal assistance : the Company chose Milne-Watson for this work. Once there his administrative abilities developed rapidly; he became general manager in 1903 and managing director in 1916. Two years later he became governor, a position giving him the supreme leadership of the Company. He held this post until April last-a term of forty-eight years with the Company.

This is not the place to trace the development of the Gas Light and Coke Co. under his leadership. It provides a highly efficient service for Greater London north of the river; indeed it stretches from Windsor to the North Sea, and is both the largest and the leading gas company throughout the world.

Milne-Watson became a technician as well as administrator; he appreciated to the full the part that science should play in the gas industry and provided full opportunity both for research and development. He was responsible for the installation of adequately equipped and staffed research laboratories to deal with gas manufacture, tar products and the utilization of gas.

Milne-Watson had the inspiration at an early stage to enlist the co-operation of Sir Harold Hartley, and the edifice created between them has placed the gas industry in the forefront of those industries which by research work in all the sciences are continually giving better service to the public. So far from being effete, as is sometimes suggested, the gas industry is in the very forefront of progress, an achievement which redounds very largely to the credit of Milne-Watson.

Milne-Watson realized also the responsibility which lies on a large firm to promote the education of its employees. Every encouragement and special facilities for study were provided, while MilneWatson himself served on several important committees dealing with education. As the leader of the gas industry in Britain he could not escape a large share of the co-operative work required by the industry, including the relations with labour; and here again his high qualifications made him a member of many national labour inquiries, committees and conferences, including the International Labour Office at Geneva. Space prevents reference to his many other activities, for he was unsparing of his energies in helping national and public causes.

But it is essential to stress his human qualities. $\mathrm{He}$ had the widest possible circle of business friends, to whom he was never too busy to give a word of kindly advice or lend a helping hand. In his own Company he prided himself on being the 'father' of a great family. Though forthright in utterance, he was a very lovable and much respected man. $\mathrm{He}$ became a knight in 1927 and a baronet in 1937, and had two sons and a daughter.

E. F. Armstrong.

\section{Dr. A. Lees}

Dr. Andrew Lees, of the Projectile Development Establishment (Ministry of Supply) and University College, Swansea, died suddenly, after only a few days illness, on August 29, in his thirty-fourth year.

Dr. Lees was born on November 30, 1911. He had a brilliant career at University College, Nottingham, taking the B.Se. with first-class honours in mathematies, winning the Lubbock Prize awarded by the University of London, and then taking the M.Sc. with a mark of distinction. His research work in quantum mechanics gained him a scholarship at Trinity College, Cambridge, where he studied under Prof. P. A. M. Dirac, who described him as possessing a quite unusual imagination and power of abstraction. Dr. Lees obtained the Cambridge Ph.D. degree, and was then appointed to the staff of University College, Swansea, but he had only been there about two years when war broke out.

After a short-period in the Army, Dr. Lees was transferred to the Projectile Development Establishment at Cardigan. Owing to the requirements of official secrecy, details of his work there cannot be given; but it is allowable to say that as a member of the ballistics group he made several valuable contributions to the theoretical and practical aspects of the external ballistics and fire control of anti-aircraft and other weapons. In his spare time he continued his researches in quantum mechanics and related branches of mathematical physics; at the time of his death he had two papers accepted for publication and he was engaged on a third. His correspondence shows that he had many ideas which he was hoping to develop as soon as he could be released from war duties, and his published work would, in all probability, have been considerably augmented if he had been spared for even a few more years.

We extend our deepest sympathy to his widow and two young daughters. H. T. H. Praggro. 